\title{
SUBSTITUSI TEPUNG ALMOND DENGAN TEPUNG KEMIRI (Aleurites moluccana Wild) TERHADAP KARAKTERISTIK KULIT MACARON
}

\author{
Substitution of Almond Flour with Candlenut Flour (Aleurites moluccana Wild) on the
} Characteristics of Macaron Shell

\author{
Ida Ayu Ganitri Adnyasuari ${ }^{1)}$, I Gusti Ayu Ekawati ${ }^{2)}$, Ni Made Indri Hapsari Arihantana ${ }^{2)}$ \\ ${ }^{1)}$ Mahasiswa Program Studi Imu dan Teknologi Pangan, Fakultas Teknologi Pertanian, Unud \\ ${ }^{2)}$ Dosen Program Studi Imu dan Teknologi Pangan, Fakultas Teknologi Pertanian, Unud \\ Kampus Bukit Jimbaran, Badung-Bali
}

\begin{abstract}
This research aims to identify the substitution of almond flour with candlenut flour on the characteristics of macaron shell, and to identify the right concentration of almond flour with candlenut flour on the characteristics of macaron shell. This research used randomized block design with the treatment ratio of almond flour with candlenut flour, which consists of 6 levels such as: $100 \%: 0 \%, 80 \%: 20 \%, 60 \%: 40 \%, 40 \%: 60 \%, 20 \%: 80 \%$, and $0 \%: 100 \%$. Each treatment was repeated 3 times, resulting in 18 experimental units. The data were then analyzed using Analysis of Variance and if the treatment had an effect on the parameter, the Duncan test was performed. The result showed that substitution of almond flour with candlenut flour had a significant effect on water content, ash content, protein content, fat content, carbohydrate content, swelling, flavor (hedonic), texture (hedonic), taste (scoring) and overall acceptance (hedonic). Substitution of almond flour with candlenut flour $40 \%$ had the best characteristics, with 2,40\% water content, 2,51\% ash content, 9,40\% protein content, 18,98\% fat content, 66,70\% carbohydrate content, 130,81\% swelling, color, flavor, taste, and overall acceptance liked, taste candlenut medium and texture very soft.
\end{abstract}

Keywords: almond flour, candlenut flour, macaron shell, substitution

\section{PENDAHULUAN}

Macaron merupakan jenis kue kering yang berasal dari Italia, yang kemudian diperkenalkan ke Perancis. Berdasarkan sejarahnya, macaron menjadi salah satu kue khas Perancis yang sudah dikenal banyak orang hingga ke Indonesia. Macaron adalah kue sederhana yang biasanya terbuat dari putih telur, gula, dan tepung almond dimana dua buah shell macaron atau kulit macaron direkatkan menjadi satu dan ditengahnya diberikan isian (filling) seperti ganache, cream cheese, atau butter cream. Kemunculan macaron sangat fenomenal dikarenakan bentuknya yang mungil dengan warna-warni yang menggoda, sehingga menarik perhatian orang yang melihatnya. Macaron memiliki cita rasa unik dengan tekstur yang lembut diluar dan agak kenyal saat dimakan. Proses pembuatan kulit macaron harus selalu $d r y$ and dry from start till the end of the process yang artinya dalam proses pembuatan macaron diperlukan alat-alat yang bersih dan tidak menggunakan bahan-bahan lain yang sifatnya lembab, karena dapat berpotensi menggagalkan dalam proses pembuatan macaron (Wulandari, 2013).

Bahan utama dalam pembuatan macaron adalah tepung almondyang biasa disebut dengan almond meal, almond powder atau almond ground. Almond banyak digunakan dalam produk pangan dengan tujuan meningkatkan cita rasa dan tekstur, juga memperbaiki komposisi gizi agar lebih menyehatkan (Astawan, 2009). Almond

*Korespondensi Penulis :

Email: ganitriidaayu28@gmail.com ${ }^{1}$ 
terbagi menjadi dua jenis yaitu almond yang biasa dikonsumsi oleh masyarakat yaitu almond manis karena rasanya yang enak dan biasa digunakan sebagai bahan baku almond meal, sedangkan almond pahit biasa digunakan sebagai bahan baku pembuatan minyak. Tepung almond adalah bahan makanan yang rendah karbohidrat, kaya akan vitamin, mineral, lemak, dan juga mengandung protein lebih tinggi dan lebih kaya nutrisi daripada terigu dan juga bebas gluten. Almond dan tepung almond tidak dihasilkan di Indonesia, dan harus diimpor dari luar sehingga menyebabkan harga almond dan tepung almond cukup mahal di pasaran. Oleh karena itu, dicari alternatif lain sebagai pengganti tepung almond yang karakteristiknya hampir sama dalam pembuatan macaron, salah satu pangan lokal yang dapat digunakan adalah tepung kemiri.

Kemiri (Aleurites moluccana Wild) merupakan tanaman serbaguna yang penting di Indonesia. Kemiri merupakan salah satu bahan pangan lokal yang mudah tumbuh di Indonesia dan bijinya biasa dimanfaatkan sebagai sumber minyak dan rempah-rempah. Menurut Arlene et al. (2010), batang kayu kemiri digunakan sebagai bahan pembuat pulp dan batang korek, daunnya dapat digunakan sebagai obat tradisional, bijinya biasa digunakan sebagai bumbu masak untuk penyedap dan pelezat masakan, sedangkan tempurung bijinya digunakan untuk obat nyamuk bakar dan arang. Kemiri sangat mudah ditemui di pasar tradisional hingga pasar modern dengan harga yang cukup terjangkau. Pemanfaatan kemiri biasanya banyak digunakan sebagai bahan bumbu masakan dan belum banyak diaplikasikan pada pembuatan makanan selain dijadikan sebagai bumbu masakan. Kandungan nutrisi yang terdapat pada kemiri antara lain karbohidrat, lemak dan protein serta kalium, fosfor, magnesium, kalsium dan kandungan penting lainnya seperti vitamin, folat dan fitosterol yang dapat merusak enzim pembentuk kolesterol dalam hati sehingga dapat menghambat pembentukan kolesterol.

Lemak dan protein merupakan komponen utama dalam pembuatan macaron. Karakteristik tepung kemiri terutama kandungan lemak, protein dan teksturnya hampir sama 90\% dengan tepung almond, berdasarkan hal tersebut maka perlu dilakukan penelitian untuk mensubstitusikan tepung almonddengan tepung kemiri dalam pembuatan kulit macaron.

\section{METODE PENELITIAN}

\section{Tempat dan Waktu Penelitian}

Penelitian ini dilaksanakan di Laboratorium Pengolahan Pangan, Laboratorium Analisis Pangan, Laboratorium Teknik Pasca Panen, dan Laboratorium Rekayasa Proses dan Pengendalian Mutu, Fakultas Teknologi Pertanian, Universitas Udayana, SudirmanDenpasar. Penelitian ini dilaksanakan pada bulan Agustus sampai dengan September 2018.

\section{Bahan dan Alat}

Bahan yang digunakan dalam penelitian ini terdiri dari bahan baku, bahan tambahan, dan bahan kimia. Bahan baku yang digunakan terdiri dari kemiri yang diperoleh di pasar Kerambitan kota Tabanan, tepung almond, gula pasir, icing sugar, dantelur (diambil bagian putihnya saja) yang diperoleh dari toko UD. Fenny Denpasar. Bahan tambahan terdiri dari tepung instan (RAP instan), cream of tartar yang diperoleh dari toko UD. Fenny Denpasar. Bahan kimia yang digunakan dalam melakukan analisis meliputi aquades, kertas saring, benang wool, heksan, tablet kjeldhal, $\mathrm{NaOH} 50 \%$, penolpthalin, asam borat, asam klorida, dan asam sulfat.

Alat-alat yang digunakan dalam proses pembuatan kulit macaron, yaitu pisau, baskom, timbangan analitik, loyang, alumunium foil, plastik, sendok, spatula, blender (Electrolux), mixer (Electrolux), oven 
(Electrolux), ayakan (40 mesh), cetakan macaron, kompor. Peralatan yang digunakan untuk analisis, yaitu beaker glass (pyrex), gelas ukur (pyrex), pipet tetes, labu lemak (pyrex), cawan porselin, desikator, oven, cawan, pinset, spatula, corong, erlenmeyer, rak tabung.

\section{Rancangan Percobaan}

Rancangan yang digunakan dalam penelitian ini adalah Rancangan Acak Kelompok (RAK) dengan perlakuan substitusi penggunaan tepung almond dengan tepung kemiri dalam pembuatan kulit macaron pada penelitian ini adalah sebagai berikut:

$\mathrm{P} 0=100 \%$ tepung almond : $0 \%$ tepung kemiri, $\mathrm{P} 1=80 \%$ tepung almond : $20 \%$ tepung kemiri, $\mathrm{P} 2=60 \%$ tepung almond : $40 \%$ tepung kemiri, P3 $=40 \%$ tepung almond : $60 \%$ tepung kemiri, P4 $=20 \%$ tepung almond : $80 \%$ tepung kemiri, P5 $=0 \%$ tepung almond : $100 \%$ tepung kemiri.

Dari masing-masing perlakuan dilakukan pengulangan sebanyak 3 kali sehingga diperoleh 18 unit percobaan. Data yang diperoleh dianalisis dengan sidik ragam dan apabila terdapat pengaruh perlakuan terhadap parameter yang diamati maka dilanjutkan dengan uji Duncan (Gomez dan Gomez, 1995).

\section{Pelaksanaan Penelitian}

\section{Tahap I Pembuatan Tepung Kemiri}

Kemiri yang akan digunakan dicuci terlebih dahulu lalu dikeringkan, kemudian dipotongpotong hingga mencapai ukuran $1 \mathrm{~cm}$ dengan menggunakan pisau untuk memperkecil ukuran. Setelah itu, kemiri dihaluskan dengan menggunakan blender. Lakukan sedikit demi sedikit untuk mencegah kemiri menggumpal dan mengeluarkan minyak, kemudian diayak dengan ayakan 40 mesh.

\section{Tahap II Pembuatan Kulit Macaron}

Bahan yang digunakan dalam pembuatan kulit macaron ditimbang sesuai formula. Formula pembuatan kulit macaron dapat dilihat pada Tabel 1.
Tabel 1. Formula Pembuatan Kulit Macaron

Keterangan: presentase berdasarkan jumlah bahan,

\begin{tabular}{lcccccc}
\hline \multirow{2}{*}{ Nama Bahan } & P1 & P2 & P3 & P4 & P5 & P6 \\
\hline $\begin{array}{l}\text { Tepung kemiri } \\
\text { (\%) }\end{array}$ & 100 & 80 & 60 & 40 & 20 & 0 \\
$\begin{array}{l}\text { Tepung almond } \\
\text { \%) }\end{array}$ & 0 & 20 & 40 & 60 & 80 & 100 \\
Putih telur (\%) & 75 & 75 & 75 & 75 & 75 & 75 \\
$\begin{array}{l}\text { Gula pasir (\%) } \\
\text { Icing sugar (\%) }\end{array}$ & 100 & 100 & 100 & 100 & 100 & 100 \\
RAP instan (\%) & 3 & 3 & 3 & 3 & 3 & 3 \\
$\begin{array}{l}\text { Cream of } \\
\text { Tartar (\%) }\end{array}$ & 3 & 3 & 3 & 3 & 3 & 3 \\
\hline \multicolumn{7}{c}{ tepung kemiri dan tepung almond yang } \\
digunakan (100\%).
\end{tabular}

Sumber: Anon., 2017

Tepung kemiri dan tepung almond dicampurkan sesuai perlakuan, kemudian ditambahkan icing sugar, dan RAP instan. Putih telur dan cream of tartar dimasukkan ke mixer dandikocok dengan kecepatan sedang. Setelah menjadi foam, dimasukkan gula pasir sedikit demi sedikit, sambil kecepatan dinaikkan hingga maksimal kemudian dikocok sampai kaku. Campuran tepung kemiri dan tepung almond (sesuai perlakuan), icing sugar, dan RAP instan dimasukkan ke dalam adonan putih telur, lalu diaduk hingga menjadi homogen.

Adonan yang sudah homogen, kemudian dimasukkan ke dalam plastik segitiga dan disemprotkan ke loyang yang sudah berisi cetakan macaron kemudian bagian bawah loyang dipukul-pukul untuk membuang udara yang terperangkap dalam adonan yang sudah dicetak. Setelah itu, didiamkan pada suhu 20 ${ }^{\circ} \mathrm{C}$ selama 30 menit sampai 1 jam dan lakukan tes dengan cara menyentuh bagian permukaan macaron. Jika sudah terasa agak mengering dan tidak menempel ketika disentuh, kemudian dimasukkan ke oven dengan suhu $135{ }^{\circ} \mathrm{C}$ selama 15 menit kemudian loyang diputar $180^{\circ}$ dan di oven kembali dengan suhu $165^{\circ} \mathrm{C}$ selama 5 menit. Kulit macaron yang telah matang didinginkan untuk selanjutnya dianalisis. 


\section{Parameter yang diamati}

Adapun parameter yang diamati dalam penelitian ini yaitu kadar air dengan metode pengeringan (Sudarmaji et al., 1997), kadar abu dengan metode pengabuan (Sudarmaji et al., 1997), kadar protein dengan metode Mikro-Kjedahl (Sudarmaji et al., 1997), kadar lemak dengan metode Soxhlet (Sudarmaji et al., 1997), kadar karbohidrat dengan metode Carbohydrate by different (Sudarmaji et al., 1997), daya kembang dengan menggunakan alat jangka sorong (Forsalina et al., 2017) dan sifat sensoris meliputi warna, rasa, aroma, tekstur dan penerimaan keseluruhan dengan menggunakan uji hedonik serta rasa dan tekstur menggunakan uji skoring (Soekarto, 1985).

\section{HASIL DAN PEMBAHASAN}

\section{Hasil Analisis Bahan Baku}

Hasil analisis kadar air, kadar abu, kadar protein, kadar lemak dan kadar karbohidrat dari tepung almond dan tepung kemiri yang digunakan dalam pembuatan kulit macaron dapat dilihat pada Tabel 1.Berdasarkan hasil analisis bahan baku diperoleh kandungan pada tepung almond: kadar air $(4,20 \%)$, kadar abu $(2,85 \%)$, kadar protein $(26,50 \%)$, kadar lemak $(54,62 \%)$, dan kadar karbohidrat $(11,82 \%)$. Kandungan pada tepung kemiri: kadar air $(4,86 \%)$, kadar abu $(2,91 \%)$, kadar protein $(19,07 \%)$, kadar lemak $(65,42 \%)$, dan kadar karbohidrat (9,00\%).

Tabel 2. Nilai rata-rata hasil analisis tepung almond dan tepung kemiri

\begin{tabular}{cccccc}
\hline Bahan & $\begin{array}{c}\text { KadarAir } \\
\mathbf{( \% )}\end{array}$ & $\begin{array}{c}\text { KadarAbu } \\
(\%)\end{array}$ & $\begin{array}{c}\text { KadarProtein } \\
(\%)\end{array}$ & KadarLemak(\%) & $\begin{array}{c}\text { Kadar } \\
\text { Karbohidrat (\%) }\end{array}$ \\
\hline Tepung Almond & 4,20 & 2,85 & 26,50 & 54,62 & 11,82 \\
Tepung Kemiri & 4,86 & 2,91 & 19,07 & 65,42 & 9,00 \\
\hline
\end{tabular}

Tabel 3. Nilai rata-rata hasil kulit macaron

\begin{tabular}{cccccc}
\hline $\begin{array}{c}\text { Tepung Almond : } \\
\text { Tepung Kemiri }\end{array}$ & $\begin{array}{c}\text { Kadar Air } \\
(\%)\end{array}$ & $\begin{array}{c}\text { Kadar Abu } \\
(\%)\end{array}$ & $\begin{array}{c}\text { Kadar Protein } \\
(\%)\end{array}$ & $\begin{array}{c}\text { Kadar Lemak } \\
(\%)\end{array}$ & Kadar Karbohidrat $(\%)$ \\
\hline P0 (100:0) & $1,78 \pm 0,09 \mathrm{~b}$ & $2,46 \pm 0,31 \mathrm{a}$ & $13,36 \pm 0,47 \mathrm{a}$ & $18,33 \pm 0,60 \mathrm{c}$ & $64,09 \pm 0,56 \mathrm{c}$ \\
P1 (80:20) & $2,23 \pm 0,21 \mathrm{~b}$ & $2,50 \pm 0,33 \mathrm{a}$ & $10,73 \pm 0,61 \mathrm{~b}$ & $18,43 \pm 0,35 \mathrm{c}$ & $66,10 \pm 0,74 \mathrm{ab}$ \\
P2 (60:40) & $2,40 \pm 0,50 \mathrm{~b}$ & $2,51 \pm 0,34 \mathrm{a}$ & $9,40 \pm 0,27 \mathrm{c}$ & $18,98 \pm 0,93 \mathrm{bc}$ & $66,70 \pm 0,33 \mathrm{a}$ \\
P3 (40:60) & $2,42 \pm 0,58 \mathrm{~b}$ & $2,53 \pm 0,36 \mathrm{a}$ & $8,72 \pm 0,48 \mathrm{c}$ & $19,68 \pm 0,51 \mathrm{ab}$ & $66,65 \pm 0,26 \mathrm{a}$ \\
P4 (20:80) & $2,50 \pm 0,32 \mathrm{~b}$ & $2,64 \pm 0,30 \mathrm{a}$ & $8,60 \pm 0,84 \mathrm{c}$ & $20,02 \pm 0,61 \mathrm{a}$ & $66,24 \pm 0,80 \mathrm{a}$ \\
P5 (0:100) & $3,36 \pm 0,53 \mathrm{a}$ & $2,64 \pm 0,20 \mathrm{a}$ & $8,52 \pm 0,38 \mathrm{c}$ & $20,53 \pm 0,34 \mathrm{a}$ & $64,94 \pm 0,87 \mathrm{bc}$ \\
\hline
\end{tabular}

Keterangan: Nilai rata - rata yang diikuti oleh huruf yang berbeda pada kolom yang sama menunjukkan berbeda nyata pada Uji Duncan $(\alpha=0,05)$.

Tabel 4. Nilai rata-rata daya kembang kulit macaron

\begin{tabular}{cc}
\hline Tepung Almond :Tepung Kemiri & Daya Kembang (\%) \\
\hline P0 (100:0) & $129,64 \pm 0,74 \mathrm{a}$ \\
P1 (80:20) & $129,51 \pm 0,59 \mathrm{a}$ \\
P2 (60:40) & $130,81 \pm 0,91 \mathrm{a}$ \\
P3 (40:60) & $130,82 \pm 0,29 \mathrm{a}$ \\
P4 (20:80) & $129,05 \pm 0,73 \mathrm{a}$ \\
P5 (0:100) & $129,88 \pm 0,96 \mathrm{a}$ \\
\hline
\end{tabular}

Keterangan: Nilai rata - rata yang diikuti oleh huruf yang berbeda pada kolom yang sama menunjukkan berbeda nyata pada Uji Duncan $(\alpha=0,05)$. 


\section{Kadar Air}

Hasil sidik ragam menunjukkan bahwa substitusi tepung almond dengan tepung kemiri berpengaruh nyata $(\mathrm{P}<0,05)$ terhadap kadar air kulit macaron. Tabel 3 menunjukkan nilai rata-rata kadar air kulit macaron berkisar antara 1,78\% sampai dengan 3,36\%. Nilai rata-rata kadar air tertinggi kulit macaron diperoleh pada perlakuan P5 yaitu 3,36\% sedangkan nilai rata-rata kadar air terendah kulit macaron diperoleh pada perlakuan $\mathrm{P} 0$ yaitu $1,78 \%$ dan berbeda tidak nyata dengan perlakuan P1, P2, P3, dan P4. Peningkatan kadar air kulit macaron yang terbuat dari tepung kemiri pada perlakuan P5 disebabkan karena adanya perbedaan kadar air pada bahan baku. Berdasarkan hasil analisis bahan baku kadar air tepung almond sebesar 4,20\% sedangkan kadar air tepung kemiri sebesar 4,86\%. Belum terdapat SNI pada produk kulit macaron.

\section{Kadar Abu}

Hasil sidik ragam menunjukkan bahwa substitusi tepung almond dengan tepung kemiri berpengaruh tidak nyata $(\mathrm{P}>0,05)$ terhadap kadar abu kulit macaron. Tabel 3 menunjukkan nilai rata-rata kadar abu kulit macaron berkisar antara $2,46 \%$ sampai dengan 2,64\%, dapat dilihat dari hasil kadar abu pada bahan baku diperoleh hasil yang tidak jauh berbeda antara tepung almond dengan tepung kemiri.

\section{Kadar Protein}

Hasil sidik ragam menunjukkan bahwa substitusi tepung almond dengan tepung kemiri berpengaruh sangat nyata $(\mathrm{P}<0,01)$ terhadap kadar protein kulit macaron. Tabel 3 menunjukkan nilai rata-rata kadar protein kulit macaron berkisar antara 8,52\% sampai dengan $13,36 \%$. Nilai rata-rata kadar protein tertinggi diperoleh dari perlakuan P0 yaitu $13,36 \%$ sedangkan nilai rata-rata terendah diperoleh dari perlakuan P5 yaitu 8,52\% serta tidak berbeda nyata dengan perlakuan P2, P3, dan P4. Semakin banyak penambahan tepung kemiri pada perlakuan P5 maka kadar protein kulit macaron semakin rendah, hal tersebut disebabkan karena adanya perbedaan kadar protein pada bahan baku. Berdasarkan hasil analisis pada bahan baku, kadar protein tepung almond sebesar 26,50\% sedangkan kadar protein tepung kemiri 19,07\%.

\section{Kadar Lemak}

Hasil sidik ragam menunjukkan bahwa substitusi tepung almond dengan tepung kemiri berpengaruh sangat nyata $(\mathrm{P}<0,01)$ terhadap kadar lemak kulit macaron. Tabel 3 menunjukkan nilai rata-rata kadar lemak kulit macaron berkisar antara $18,33 \%$ sampai dengan 20,53\%. Nilai rata-rata kadar lemak tertinggi diperoleh dari perlakuan P5 yaitu $20,53 \%$ serta tidak berbeda nyata dengan perlakuan P3 dan P4 sedangkan nilai rata-rata kadar lemak terendah diperoleh perlakuan P0 yaitu $18,33 \%$ serta tidak berbeda nyata dengan perlakuan P1 dan P2. Semakin banyak penambahan tepung kemiri maka kadar lemak yang dihasilkan semakin tinggi, hal tersebut disebabkan karena perbedaan kadar lemak pada bahan baku dimana kandungan lemak tepung kemiri lebih tinggi daripada kandungan lemak pada tepung almond, yaitu tepung almond sebesar 54,62\% sedangkan tepung kemiri $65,42 \%$.

\section{Kadar Karbohidrat}

Hasil sidik ragam menunjukkan bahwa subtitusi tepung alomd dengan tepung kemiri berpengaruh sangat nyata $(\mathrm{P}<0,01)$ terhadap kadar karbohidrat kulit macaron. Tabel 3 menunjukkan nilai rata-rata kadar karbohidrat berkisar antara 64,09\% sampai dengan $66,70 \%$. Nilai rata-rata kadar karbohidrat tertinggi diperoleh dari perlakuan P2 yaitu $66,70 \%$ serta tidak berbeda nyata dengan nyata dengan perlakuan P1, P3, dan P4 sedangkan nilai rata-rata kadar karbohidrat terendah diperoleh dari perlakuan P0 yaitu $64,09 \%$ serta tidak berbeda nyata dengan 
perlakuan P5 yaitu 64,94\%. Nilai kadar karbohidrat yang diperoleh berhubungan dengan nilai dari kadar air, kadar abu, kadar protein, dan kadar lemak yang dihasilkan karena menggunakan metode Carbohydrate by different.

\section{Daya Kembang}

Hasil sidik ragam menunjukkan bahwa substitusi tepung almond dengan tepung kemiri berpengaruh tidak nyata $(\mathrm{P}>0,05)$ terhadap daya kembang kulit macaron. Tabel 4 menunjukkan nilai rata-rata daya kembang kulit macaron berkisar $129,05 \%$ sampai dengan 130,82\%. Daya kembang terjadi dikarenakan penggunaan putih telur pada formula sehingga menyebabkan muculnya "kaki" pada kulit macaron yang merupakan ciri khas dari produk tersebut. Daya kembang dipengaruhi oleh protein, amilopektin dan lemak. Hal tersebut karena protein akan mengalami denaturasi sehingga menyebabkan produk Tabel 5. Nilai rata-rata uji hedonik kulit macaron.

\begin{tabular}{|c|c|c|c|c|c|}
\hline Tepung Almond : Tepung Kemiri & Warna & Aroma & Tekstur & Rasa & $\begin{array}{l}\text { Penerimaan } \\
\text { Keseluruhan }\end{array}$ \\
\hline P0 (100:0) & $5,67 \mathrm{a}$ & $5,67 \mathrm{~b}$ & $5,97 \mathrm{a}$ & $5,77 \mathrm{a}$ & $5,63 \mathrm{abc}$ \\
\hline P1 (80:20) & $5,83 \mathrm{a}$ & $5,70 \mathrm{~b}$ & $5,70 \mathrm{a}$ & $5,77 \mathrm{a}$ & $5,83 \mathrm{ab}$ \\
\hline P2 $(60: 40)$ & $6,03 \mathrm{a}$ & $6,07 \mathrm{a}$ & $5,87 \mathrm{a}$ & $5,80 \mathrm{a}$ & 5,93 a \\
\hline P3 (40:60) & $5,63 \mathrm{a}$ & $5,87 \mathrm{ab}$ & $5,77 \mathrm{a}$ & $5,37 \mathrm{a}$ & $5,43 \mathrm{c}$ \\
\hline P4 (20:80) & $5,70 \mathrm{a}$ & $5,67 \mathrm{~b}$ & $5,53 \mathrm{a}$ & $5,47 \mathrm{a}$ & $5,53 \mathrm{bc}$ \\
\hline P5 (0:100) & $5,67 \mathrm{a}$ & $5,60 \mathrm{~b}$ & $5,63 \mathrm{a}$ & $5,43 a$ & $5,27 \mathrm{c}$ \\
\hline
\end{tabular}

Keterangan: Nilai rata-rata yang diikuti oleh huruf yang berbeda pada kolom yang sama menunjukkan berbeda nyata $(\alpha=0,05)$

Kriteria hedonik: 1 (sangat tidak suka); 2 (tidak suka); 3 (agak tidak suka); 4 (biasa); 5 (agak suka); 6 (suka); 7 (sangat suka)

Tabel 6. Nilai rata-rata uji skoring terhadap tekstur dan rasa macaron

\begin{tabular}{ccc}
\hline Tepung Almond : Tepung Kemiri & Tekstur & Rasa \\
\hline P0 (100:0) & $3,93 \mathrm{a}$ & $2,07 \mathrm{~d}$ \\
P1 (80:20) & $3,67 \mathrm{ab}$ & $2,73 \mathrm{c}$ \\
P2 (60:40) & $3,73 \mathrm{ab}$ & $2,83 \mathrm{bc}$ \\
P3 (40:60) & $3,70 \mathrm{ab}$ & $3,20 \mathrm{bc}$ \\
P4 (20:80) & $3,17 \mathrm{c}$ & $3,27 \mathrm{~b}$ \\
P5 (0:100) & $3,37 \mathrm{bc}$ & $4,30 \mathrm{a}$ \\
\hline
\end{tabular}

Keterangan: Nilai rata-rata yang diikuti oleh huruf yang berbeda pada kolom yang sama menunjukkan berbeda nyata $(\alpha=0,05)$.

Nilai skoring tekstur: 1 (tidak empuk); 2 (agak empuk); 3 (empuk); 4 (sangat empuk); 5 (amat sangat empuk)

Nilai skoring rasa: 1 (tidak terasa kemiri); 2 (rasa kemiri lemah); 3 (rasa kemiri sedang); 4 (rasa kemiri agak kuat); 5 (rasa kemiri sangat kuat). sulit mengembang, sedangkan amilopektin bersifat merangsang terjadinya pengembangan. Lemak dapat berinteraksi dengan pati dan mencegah hidrasi sehingga sehingga menghasilkan gelatinisasi yang tinggi dan akan membentuk produk yang kurang mengembang.

\section{Sifat Sensoris} penelitian ini dilakukan dengan uji hedonik (kesukaan) terhadap parameter warna, aroma, tekstur, rasa, dan penerimaan keseluruhan terhadap warna, aroma, tekstur, rasa, dan penerimaan keseluruhan kulit macaron dapat dilihat pada Tabel 5. Nilai rata-rata uji skoring terhadap tekstur dan rasa dapat dilihat pada Tabel 5. peningkatan viskositas menjadi rendah, lemak 


\section{Warna}

Hasil sidik ragam menunjukkan bahwa substitusi tepung almond dengan tepung kemiri berpengaruh tidak nyata $(\mathrm{P}>0,05)$ terhadap warna kulit macaron. Tabel 5 menunjukkan nilai rata-rata kesukaan panelis terhadap warna kulit macaron berkisar antara 5,63 (agak suka) sampai dengan 5,83 (suka). Perbedaan konsentrasi tepung almond dengan tepung kemiri tidak berpengaruh secara signifikan terhadap warna yang dihasilkan. Hal tersebut disebabkan karena bahan baku yang digunakan memiliki warna yang sama sehingga tidak mempengaruhi tingkat kesukaan warna.

\section{Aroma}

Hasil sidik ragam menunjukkan bahwa substitusi tepung almond dengan tepung kemiri berpengaruh sangat nyata $(\mathrm{P}<0,01)$ terhadap aroma kulit macaron. Tabel 5 menunjukkan nilai rata-rata kesukaan panelis terhadap aroma kulit macaron berkisar antara 5,6 (suka) sampai dengan 6,07 (suka). Hal ini disebabkan karena campuran dari almond dan kemiri membentuk aroma yang khas. Menurut Meilgaard(2000), aroma makanan yang timbul disebabkan oleh terbentuknya senyawa volatile yang mudah menguap, proses pemasakkan yang berbeda akan menimbulkan aroma yang berbeda.

\section{Tekstur}

Hasil sidik ragam menunjukkan bahwa substitusi tepung almond dengan tepung kemiri berpengaruh tidak nyata $(\mathrm{P}>0,05)$ terhadap uji hedonik tekstur dan berpengaruh sangat nyata $(\mathrm{P}<0,01)$ terhadap uji skoring tekstur. Tabel 5 menunjukkan nilai rata-rata nilai uji hedonik tekstur terhadap kulit macaron berkisar antara 5,53 sampai dengan 5,97 dengan kriteria suka. Tingkat kesukaan panelis terhadap tekstur kulit macaron dipengaruhi oleh keempukan dari kulit macaron tersebut, dimana semakin tinggi konsentrasi tepung kemiri menghasilkan tekstur yang agak renyah dibandingkan dengan kontrol (P0).

Tabel 6 menunjukkan nilai rata-rata uji skoring tekstur terhadap kulit macaron berkisar antara 3,17 (empuk) sampai dengan 3,93 (sangat empuk). Nilai uji skoring rasa tertinggi diperoleh dari perlakuan P0 yaitu 3,93 sedangkan nilai rata-rata terendah rasa diperoleh dari P4 yaitu 3,17. Semakin tinggi konsentrasi tepung kemiri pada kulit macaron menghasilkan tekstur yang kurang empuk, hal tersebut disebabkan karena adanya pati dan putih telur yang menyebabkan kulit macaron mengembang, namun adanya kandungan lemak yang cukup tinggi yang terkandung pada tepung kemiri menyebabkan tekstur produk makin padat maka tekstur kult macaron menjadi kurang empuk tetapi tidak mempengaruhi pengembangan volume kulit macaron. Menurut Widiawati dan Anjani (2017) tekstur dipengaruhi oleh lemak pada bahan, cookies yang mengandung kadar lemak tinggi akan mudah dipatahkan jika dibandingkan dengan kadar lemak yang rendah.

\section{Rasa}

Hasil sidik ragam menunjukkan bahwa substitusi tepung almond dengan tepung kemiri berpengaruh tidak nyata $(\mathrm{P}>0,05)$ terhadap uji hedonik rasa dan berpengaruh sangat nyata $(\mathrm{P}<0,01)$ terhadap uji skoring rasa. Tabel 5 menunjukkan nilai rata-rata uji hedonik rasa terhadap kulit macaron berkisar antara 5,37 (agak suka) sampai dengan 5,8 (suka). Tingginya konsentrasi tepung kemiri pada kulit macaron tidak mempengaruhi rasa karena manis dari penambahan gula mendominasi rasa dari kulit macaron.

Tabel 6 menunjukkan nilai rata-rata uji skoring rasa terhadap kulit macaron berkisar antara 2,07 (rasa kemiri lemah) sampai dengan 4,3 (rasa kemiri agak kuat). Nilai ratarata uji skoring rasa tertinggi diperoleh dari perlakuan P5 yaitu 4,3 sedangkatn nilai ratarata uji skoring rasa terendah diperoleh dari 
perlakuan P0 yaitu 2,07. Semakin tinggi konsentrasi tepung kemiri menghasilkan rasa kemiri yang sangat kuat pada kuli macaron dan kemiri juga memiliki rasa yang khas dibandingkan dengan almond.

\section{Penerimaan Keseluruhan}

Hasil sidik ragam menunjukkan bahwa substitusi tepung almond dengan tepung kemiri berpengaruh sangat nyata $(\mathrm{P}<0,01)$ terhadap uji hedonik penerimaan keseluruhan kulit macaron. Tabel 5 menunjukkan nilai rata-rata uji hedonik penerimaan keseluruhan kulit macaron berkisar antara 5,27 dengan kriteria agak suka sampai dengan 5,93 dengan kriteria suka. Nilai rata-rata tertinggi uji hedonik kulit macaron diperoleh dari perlakuan P2 yaitu 5,93 sedangkan nilai ratarata terendah uji hedonik kulit macaron diperoleh dari perlakuan P5 yaitu 5,27. Penerimaan keseluruhan dipengaruhi oleh beberapa faktor seperti warna, aroma, tekstur, dan rasa.

\section{SIMPULAN DAN SARAN}

\section{Kesimpulan}

Bedasarkan hasil penelitian ini dapat disimpulkan sebagai berikut :

1. Substitusi tepung almond dengan tepung kemiri berpengaruh nyata terhadap kadar air, kadar protein, kadar lemak, kadar karbohidrat, sifat sesoris hedonik penerimaan keseluruhan, sifat sensoris skoring pada tekstur dan rasa. Substitusi tepung almond dengan tepung kemiri tidak berpengaruh nyata terhadap kadar abu, daya kembang, sifat sensoris hedonik pada warna, teksur dan rasa.

2. Substitusi tepung almond dengan tepung kemiri $40 \%$ dapat menghasilkan karakteristik terbaik dengan kriteria kadar air 2,40\%, kadar abu 2,51\%, kadar protein 9,40\%, kadar lemak 18,98\%, kadar karbohidrat $66,70 \%$, daya kembang $130,81 \%$, dengan warna suka, aroma suka, tekstur sangat empuk dan suka, rasa kemiri sedang dan suka, serta penerimaan keseluruhan disukai.

3. Tepung kemiri dapat menggantikan tepung almond dalam pembuatan kulit macaron dengan kerakteristik yang hampir sama namun kulit macaron yang terbuat dari tepung kemiri memiliki tekstur yang renyah dan rasa kemiri yang dominan.

\section{Saran}

Berdasarkan penelitian diatas dapat dilakukan penelitian lebih lanjut dengan menambahkan esens atau perasa untuk mengurangi rasa kemiri yang dominan serta menambahkan pewarna alami dalam proses pembuatan kulit macaron sehingga dapat menambah daya tarik terhadap produk kulit macaron.

\section{DAFTAR PUSTAKA}

Anonimus. 2017. Formula Bahan-Bahan yang Digunakan dalam Pembuatan Kulit Macaron. Kulinair Food Solutions. Tuban. Bali.

Arlene, A., Ign. Suharto, dan Jessica N.R. 2010. Pengaruh Temperatur dan Ukuran Biji Terhadap Perolehan Minyak Kemiri pada Ekstraksi Biji Kemiri dengan Penekanan Mekanis. Prosiding Seminar Nasional Teknik Kimia "Kejuangan". Universitas Katolik Parahyangan. Yogyakarta.

Astawan, M. 2009. Sehat dengan Hidangan Kacang dan Biji-Bijian. Penebar Swadaya. Jakarta.

Forsalina, F., K.A. Nocianitri, dan I.D.P.K. Pratiwi. 2017. Pengaruh substitusi terigu dan tepung beras merah (Oryza nivara) terhadap karakteristik bakpao. Jurnal Ilmu dan Teknologi Pangan (ITEPA). Vol. 5, no 2, p. 40-50. 
Gomez, K. A. dan A. A. Gomez. 1995. Prosedur Statistik Untuk Penelitian Pertanian. UI Press, Jakarta.

Meilgaard. 2000. Sensory evaluation techniques. Boston: CRC.

Sudarmadji, S., B. Haryono, dan Suhardi. 1997. Prosedur Analisa untuk Bahan Makanan dan Pertanian. Penerbit Liberty: Yogyakarta.

Soekarto, S.T. 1985. Penilaian Organoleptik Untuk Industri Pangan dan Pertanian. Bharata Karya Aksara: Jakarta.

Widiawati A. dan Anjani, G. 2017. Cookies Tepung Beras Hitam dan Kedelai Hitam sebagai Alternatif Makanan Selingan Indeks Glikemik Rendah. Journal of Nutrition College. Program Studi Ilmu Gizi Fakultas Kedokteran Universitas Diponegoro. Volume 6, Nomor 2, Tahun 2017, Halaman 128-137.

Wulandari, N. 2013. A-Z Macaron. Halimun Media Citra. Jakarta. 